\title{
APLIKASI PENJADWALAN PIKET HARI LIBUR BAGI KARYAWAN PT. ASTRA INTERNASIONAL.TbK (AUT0 2000) PALEMBANG
}

\author{
Acep Juliandri \\ PT. Astra Internasiona, Tbk (Auto 2000) Plaju Palembang \\ Sur-el : acep09071994@gmail.com,
}

\begin{abstract}
From the results of research conducted on the data or information obtained about the needs that are needed, it will become the employee scheduling application program. To do data processing, employee scheduling at PT. Astra Internasional, Tbk ( Auto2000) Palembang which provides sales, maintenance, repair and supply of Toyota spare parts that are still being done using Excel Office Microsoft. How to make a schedule that takes a long time? To overcome these problems, it is necessary to have a new computerized system to improve work efficiency by making PT. Astra Internasional, Tbk ( Auto2000) Palembang Employee Picking Application Schedule. This system produces, Employee Pickup Schedule using PHP and MySQ.
\end{abstract}

Keywords : PT. Astra Internasional, Tbk (Auto 2000), Employee Schedules, Php, MySQL

\begin{abstract}
Abstrak : Berdasarkan hasil penelitian yang penulis lakukan terhadap data atau informasi yang di peroleh terdapat kebutuhan yang mendesak akan suatu program aplikasi Penjadwala karyawan. Untuk melakukan pengolahan data Penjadwalan karyawan pada PT. Astra Internasional, Tbk (Auto2000) Palembang yang melayani jasa penjualan, perawatan, perbaikan dan penyediaan suku cadang Toyota yang masih di lakukan dengan mengunakan Microsoft office excel. Akibatnya dalam pembuatan Jadwal piket karyawan sangat kurang efektif dan efesien dan membutuhkan waktu yang sangat lama. Untuk mengatasi masalah-masalah tersebut, diperlukan adanya sistem yang terkomputerisasi yang baru untuk meningkatkan efisiensi kerja dengan membuat Aplikasi Penjadwalan Piket Karyawan PT. Astra Internasional, Tbk (Auto2000) Palembang. Sistem ini menghasilan, Laporan Jadwal Piket Karyawan menggunaka Php dan MySQL.
\end{abstract}

Kata kunci : PT. Tunas Auto Graha(Auto 2000), Jadwal Piket Karyawan, Php, MySQL

\section{PENDAHULUAN}

Perkembangan dunia usaha saat ini dihadapkan pada situasi atau kondisi persaingan yang semakin ketat dan juga perkembangan dunia informasi yang semakin meningkat seiring dengan semakin berkembangnya ilmu pengetahuan dan teknologi komputer yang mampu menunjang sebagai kebutuhan dan permintaan informasi dari pengguna-pengguna membuat informasi telah menjadi suatu kebutuhan dan permintaan informasi dari pengguna membuat infromasi telah menjadi suatu kebutuhan dalam sebuah perusahaan. Oleh karena itu, sarana yang cepat dan tepat untuk mengakses, mengolah dan menyimpan sumber informasi ini menjadi bagian yang tidak terpisahkan dalam kegiatan usaha.

PT. Astra Internasional, Tbk merupakan perusahaan yang mengelola atau memanajamen jasa penjualan, perawatan, perbaikan dan penyediaan suku cadang Toyota yang dikenal dengan nama Auto 2000. Auto 2000 Palembang berkembang pesat karena memberikan berbagai layanan yang sangat memudahkan bagi calon pembeli maupun pengguna Toyota. Dengan slogan "Urusan Toyota jadi mudah!” Auto2000 selalu mencoba menjadi yang terdepan dalam 
pelayanan. Produk-produk Auto2000 yang inovatif seperti THS (Toyota Home Service), Express Maintenance (servis berkala hanya satu jam). Dengan jumlah karyawan 128 orang baik karyawan tetap atau karyawan outsourcing.

Sebagai perusahaan jasa yang melayani konsumen, Auto 2000 berusaha untuk selalu siap untuk melayani kebutuhan konsumen. Bukan hanya pada hari kerja, saat hari libur pun pelayanan konsumen harus dilakukan. Jadwal kerja karyawan pada hari kerja, sudah dilaksanakan secara komputerisasi. Namun untuk penjadwalan piket karyawan pada hari libur, masih di lakukan secara konvensional dengan bantuan aplikasi Microsoft Excell. Sistem Penjadwalan dengan cara tersebut dirasa belum maksimal, dikarenakan sering terjadi penjadwalan yang berulang untuk karyawan yang sama dan terdapat karyawan yang belum atau bahkan tidak pernah mendapatkan jadwal piket di hari libur. Penjadwalan dapat diartikan sebagai pengalokasian sejumlah sumber daya (resource) untuk melakukan sejumlah tugas atau operasi dalam jangka waktu tertentu dan merupakan proses pengambilan keputusan yang peranannya sangat penting dalam industri manufaktur dan jasa yaitu mengalokasikan sumber-sumber daya yang ada agar tujuan dan sasaran perusahaan lebih optimal (Baker \& Trietsch, 2009). Definis lain menyebutkan penjadwalan dapat didefinisikan sebagai proses pengalokasian sumber daya untuk mengerjakan sekumpulan tugas dalam jangka waktu tertentu dengan 2 arti penting, yaitu:

a) Penjadwalan merupakan suatu fungsi pengambilan keputusan untuk membuat atau menentukan jadwal, b) Penjadwalan merupakan suatu teori yang berisi sekumpulan prinsip dasar, model, teknik, dan kesimpulan logis dalam proses pengambilan keputusan yang memberikan pengertian dalam fungsi penjadwalan. Pinedo (2012).

Penelitian ini bertujuan untuk membangun Aplikasi Penjadwalan Piket Hari Libur Bagi Karyawan Auto 2000. Aplikasi berbasis komputer yang dibangun diharapakan dapat membantu dalam menjadwalkan piket bagi Karyawan pada hari libur, agar dapat tersebar secara merata. Aplikasi berbasis Komputer merupakan suatu sistem yang dirancang dan disusun sedemikian rupa untuk menghasilakn informasi yang terpadu sebagai sarana penunjang. (Jogiyanto, 2004)

Aplikasi akan dibangun menggunakan bahasa Pemrograman $P H P$ dan $M y S Q L$ sebagai pengolahan basis data (database). Menurut Agus Saputra (2011) PHP atau yang memiliki kepanjangan Hypertext Preprocessor merupakan suatu bahasa pemrograman yang difungsikan untuk membangun suatu website dinamis. PHP dapat digunakan dengan gratis (free) dan bersifat Open Source. Sedangkan MySQL adalah software yang dapat mengelola database dengan sangat cepat,dapat menampung data dalam jumlah sangat besar, dapat diakses oleh banyak user (multi-user),dan dapat melakukan suatu proses singkronasi atau berbarangan (multi-threaded). (Raharjo, 2011).

\section{METODOLOGI PENELITIAN}

\subsection{Metode Penelitian}

Metode yang digunakan dalam penelitian ini penelitian yang digunakan adalah Metode 
Deskriptif. Metode deskriptif adalah metode yang digunakan untuk menganalisis data dengan cara mendeskripsikan atau menggambarkan data yang telah terkumpul sebagaimana adanya tanpa bermaksud membuat kesimpulan yang berlaku untuk umum atau generalisasi. (Sugiyono, 2013)

\subsection{Metode Pengumpulan Data}

Pengumpulan data merupakan langkah yang paling strategis dalam penelitian, karena tujuan utama dari penelitian adalah mendapatkan data. Sugiyono (2013). Teknik pengumpulan dta yang dilakukan dalam penelitian ini adalah; 1)Teknik Observasi, Yaitu proses penngamatan langsung ke Auto 2000 Palembang pada bagian administrasi pengaturan jadwal piket yang dilakukan selama ini, 2) Teknik Wawancara, yaitu dengan cara bertanya langsung kepada pihak-pihak yang terkait dalam memberikan informasi pengenai pengolahan data yang dilakukan pada Auto2000 Plaju, khususya bagian yang mengatur jadwal piket yang selama ini berjalan di Auto2000 Plaju, 3)Teknik Dokumentasi, yaitu informasi tentang data pegawai, data struktur organisasi, data tugas dan tanggung jawab karyawan.

\subsection{Tahapan Pengembangan Sistem}

Metode perancangan system yang digunakan adalah metode System Development Life Cycle (SLDC) Air Terjun(Waterfall). Menurut pressman (2010), model waterfall adalah model klasik yang bersifat sistematis, berurutan dalam membangun software. Nama model ini sebenarnya adalah "Linear Sequential
Model". Model ini sering disebut dengan "classic life cycle" atau model waterfall, sering dianggap kuno, tetapi merupakan model yang paling banyak dipakai di dalam Software Engginering (SE). Model ini melakukan pendekatan secara sistematis dan berurutan. Disebut dengan waterfall karena tahap demi tahap yang dilalui harus menunggu selesainya tahap sebelumnya dan berjalan berurutan. Gambar 1 menunjukkan tahapan pada model Waterfall.

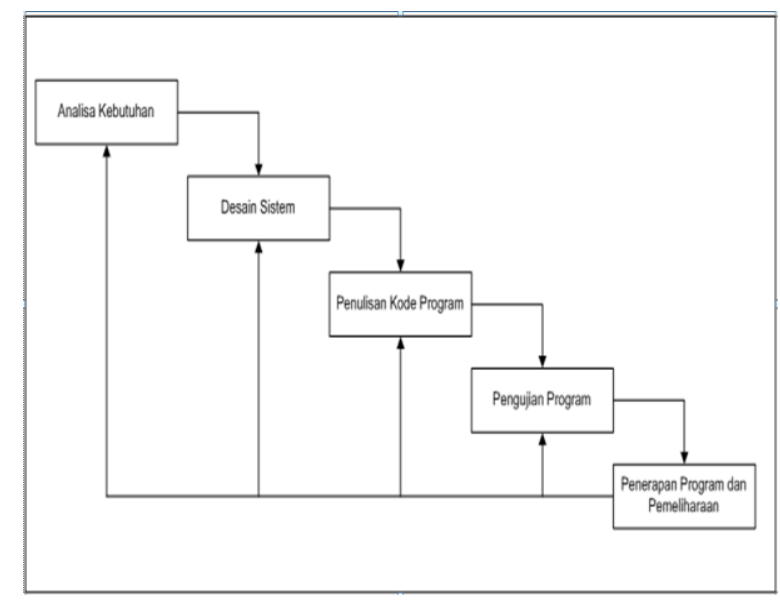

Gambar 1 Waterfall Model

Model tersebut meliputi kegiatan aktivitas sebagai berikut; 1) Analisa Kebutuhan, merupakan tahapan menganalisa hal-hal yang diperlukan dalam pelaksanaan proyek pembuatan perangkat lunak, 2) Desain Sistem, merupakan perancangan berdasarkan analisis data ke dalam bentuk gambar aplikasi yang dibuat, 3) Penulisan Kode Program, merupakan penerapan hasil perancangan dari aplikasi yang di bangun ke dalam bahasa pemrograman, 4) Pengujian Program, merupakan pengujian terhadap aplikasi yang dibangun, 5) Penerapan Program dan Pemeliharaan, merupakan tahap akhir dimana suatu perangkat lunak yang sudah selesai dapat mengalami perubahan perubahan atau penambahan sesuai dengan permintaan user. 


\subsection{Penelitian Terdahulu}

Penelitian yang dilakukan oleh Andrie Tri Laksono, Meinarini Catur Utami, Yuni Sugiarti (2016), Universitas Islam Negeri Syarif Hidayatullah Jakarta, dengan Judul Sistem Penjadwalan Kuliah Menggunakan Metode Algoritma Genetika (Studi Kasus: Fakultas Kedokteran Dan Kesehatan Universitas Muhammadiyah Jakarta). Penelitian ini bertujuan merancang Sistem Informasi Penjadwalan Perkuliahan Berbasis Web dengan Metode Algoritma Genetika yang merupakan sarana terkait proses penentuan jadwal perkuliahan. Sistem ini digunakan untuk FKK UMJ bidang akademik dalam membuat jadwal perkuliahan, serta memudahkan staf akademik, dosen dan mahasiswa mengakses data penjadwalan kuliah. Metode penjadwalan menggunakan Algoritma Genetika, Hasil penelitian ini dapat memberikan kemudahan dalam mengelola penjadwalan kuliah yang tepat sesuai kesiapan waktu dosen mengajar dan lokal yang tersedia sehingga membantu proses pembuatan jadwal perkuliahan menjadi lebih baik lagi.

\section{HASIL DAN PEMBAHASAN}

\subsection{Analisis Sistem Berjalan}

Auto 2000 Palembang yang langsung berada di bawah PT. Astra Internasional Tbk, sebagai perusahaan pelayanan jasa dibidang otomotif untuk produk Toyota mempunyai total 134 karyawan. Sebagai perusahaan yang bergerak di bidang penjualan dan pelayanan service kendaraan Auto 2000 diharuskan untuk tetap buka pada saat hari minggu ataupun libur nasional, untuk memenuhi kebutuhan manpower saat adanya hari minggu atau hari libur nasional maka Auto 2000 diharuskan menyusun daftar piket karyawan, yang dimana setiap hari minggu dan hari libur nasional Auto 2000 harus mempunyai setidaknya sepuluh karyawan yang harus bekerja dalam satu shift kerja. Saat ini penyusunan jadwal piket karyawan pada hari libur masih bersifat manual yakni belum terkomputerisasi dengan baik, dimana semua proses pencatatan jadwal piket karyawan di catatat kedalam Microsoft exel.

Setiap awal bulan jadwal piket Karyawan di jadwalkan oleh seorang administrasi yang kemudian dicatat ke dalam Microsoft exel, Kemudian jadwal piket tersebut di print. Setelah Jadwal telah Selesai dibuat maka adminisrasi bertugas melaporkan jadwal piket karyawan tersebut kepada seluruh kepala departemen untuk mendapat persetujuan dari masing masing kepala departemen dan juga admin bertugas untuk mensosialisasikan jadwal piket karyawan Auto 2000 Palembang. setelah mendapatkan persetujuan dari kepala departemen barulah jadwal piket karyawan disosialisasikan atau di informasikan kepada Karyawan melalui papan pengumuman.

Masalah yang sering timbul dari sistem penjadwalan yang dilakukan saat ini adalah penyebaran karyawan piket pada libur yang tidak merata. Terdapat karyawan yang sering mendapatkan jadwal piket, namun ada juga yang belum bahkan tidak pernah mendapatkan jadwal piket pada hari libur. 


\subsection{Rancangan Sistem}

Perancangan dilakukan berdasarkan hasil dari analisis. Perancangan digunakan untuk menggambarkan bagaimana sistem akan dibangun. Bagian-bagian dari perancangan sistem ini adalah Data Flow Diagram (DFD)

Rancangan basis data, rancangan tampilan aplikasi dan rancangan tampilan laporan.
Adapun rancangan-rancangan tersebut adalah sebagai berikut.

\section{A. Data Flow Diagram (Konteks)}

Data Flow DiagramKonteks pada gambar 1 menggambarkan suatu lingkaran besar yang dapat mewakili seluruh proses yang terdapat dalam sistem penjadwalan piket karyawan auto 2000 Palembang.

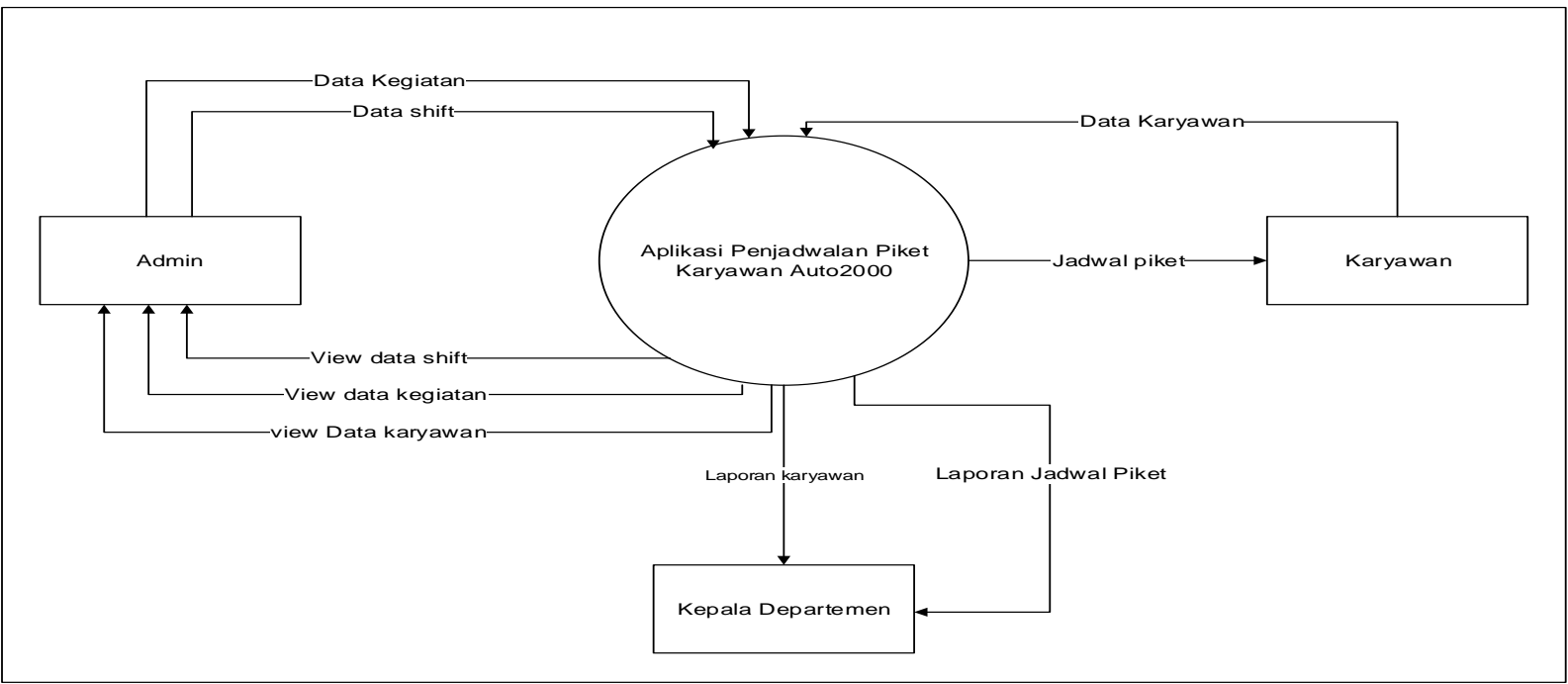

Gambar 2 Data Flow Diagram konteks aplikasi penjadwalan piket karyawan

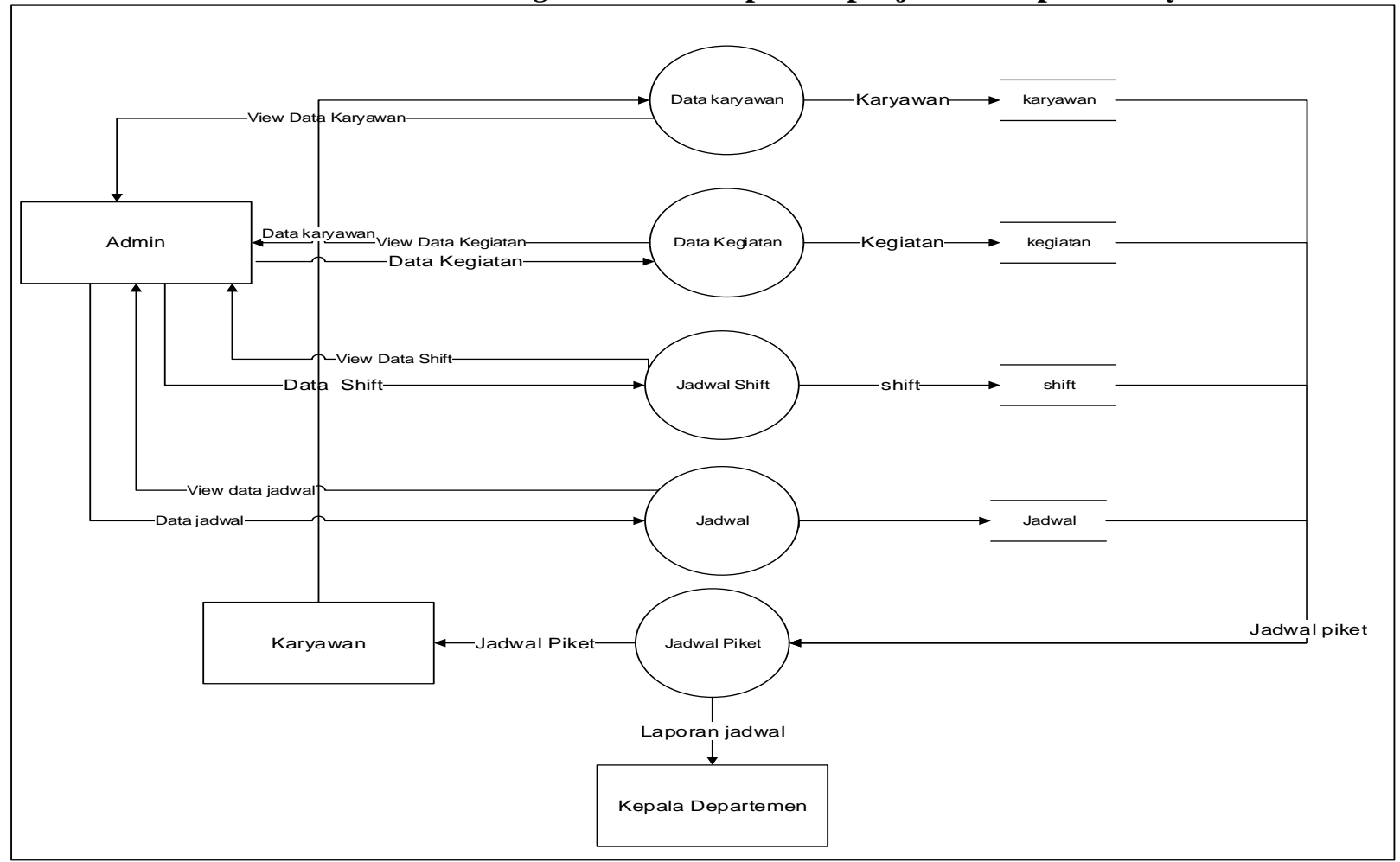

Gambar 3 Data Flow Diagram Aplikasi penjadwalan piket karyawan 


\section{B. DFD (Data Flow Diagram)}

Data Flow Diagram yang ditunjukkan pada gambar 3, menjelaskan tentang pembuatan model sistem untuk menggambarkan jaringan proses fungsional yang dihubungkan satu sama lain dengan alur data sistem penjadwalan piket karyawan auto 2000 Palembang.

\section{c. Entity Relationship Diagram (ERD)}

Entity Relationship Diagram (ERD) menjelaskan suatu hubungan data data pada suatu basis data. ERD Aplikasi yang dibangun dapat dilihat pada gambar 4.

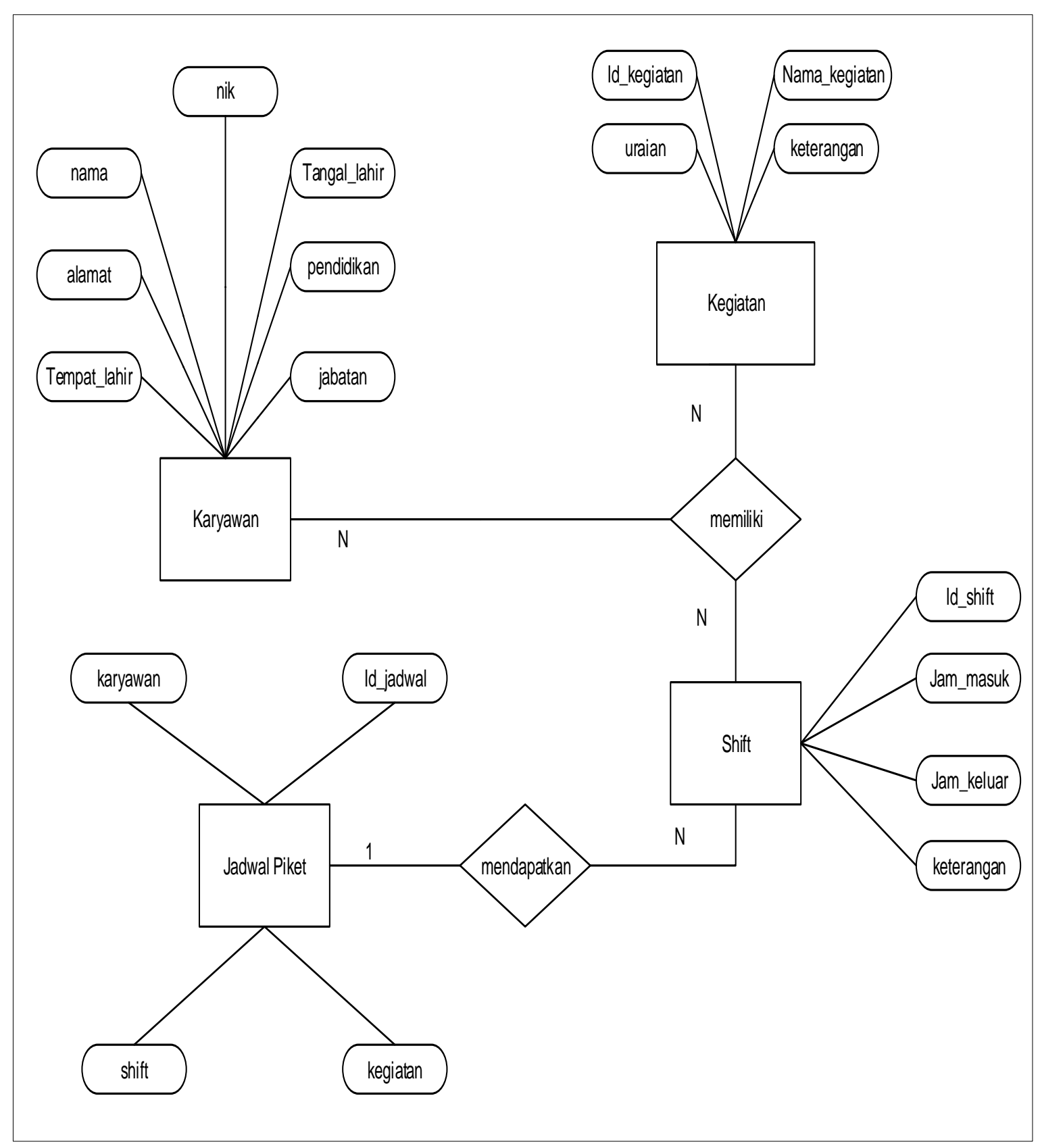

Gambar 4 Entity Relationship Diagram (ERD) 


\subsection{Rancanga Database}

Database merupakan kumpulan data secara logis yang berkaitan dalam merepresentasikan fonomena secara terstruktur dalam domain tertentu untuk mendukung aplikasi pada sistem tersebut. Basis Data untuk membangun aplikasi ini adalah sebagai berikut:

Tabel karyawan berisi beberapa field yang dirancang untuk menyimpan data karyawan terdiri dari : nik, nama, alamat, tempat_lahir, tanggal_lahir, pendidikan, jabatan.

Tabel kegiatan, dirancang untuk menyimpan data Kegiatan karyawan pada saat piket. Adapun field yang tersimpan pada database ini yaitu id_kegiatan, nama_kegiatan, keterangan.

Tabel shift, berisi beberapa kolom yaitu kolom id_shif, kolom jam_masuk, jam_keluar, keterangan. Tabel jadwal, berisi beberapa field yaitu id_jadwal, karyawan, kegiatan, shift.

\subsection{Pengkodean (Coding)}

Langkah selanjutnya, setelah melakukan perancangan sistem, Database serta interface adalah melakukan koding dengan menerapkan logika dan perancangan kedalam aplikasi pemrograman $P H P$ yang disimpan ke dalam database MySQL. Hasil coding akan berbentuk aplikasi yang siap digunakan untuk mengolah data Penjadwalan Piket hari libur Karyawan Auto 2000. Yang terdiri dari;

1. Halaman Menu Login
Tampilan Menu Login ini merupakan menu pembukaan dari aplikasi pengolahan Penjadwalan Piket karyawan.

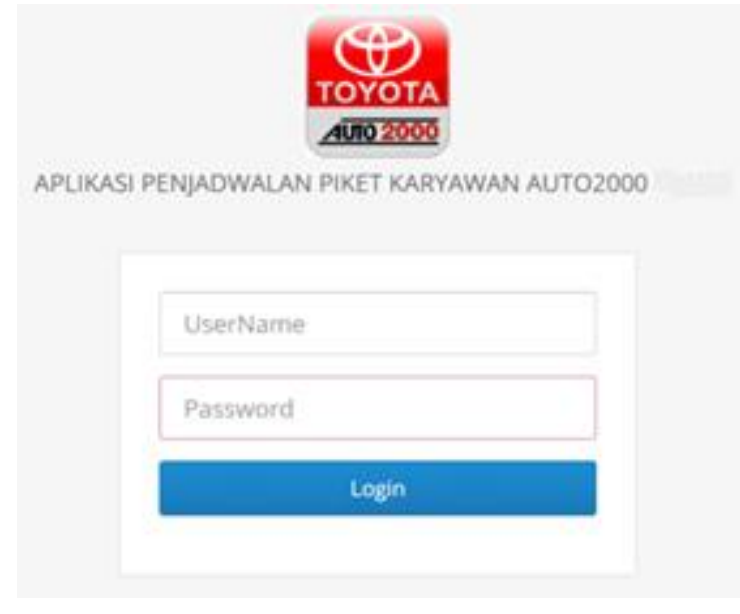

Gambar 5. Menu Login

2. Halaman Input Data Karyawan

Tampilan ini untuk menambahkan data karyawan Auto2000 palembang

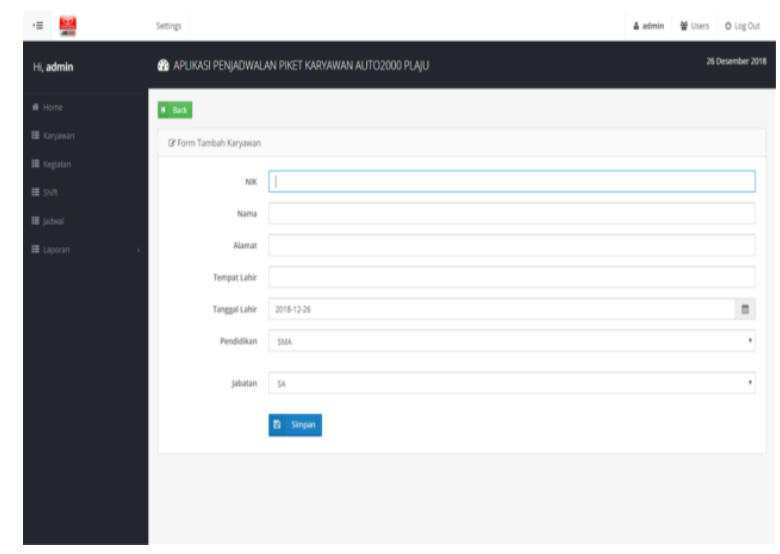

Gambar 6. input Data Karyawan

3. Halaman Menu Input Kegiatan Piket Karyawan

Tampilan ini untuk menginput kegiatan piket karyawan Auto 2000 Palembang 


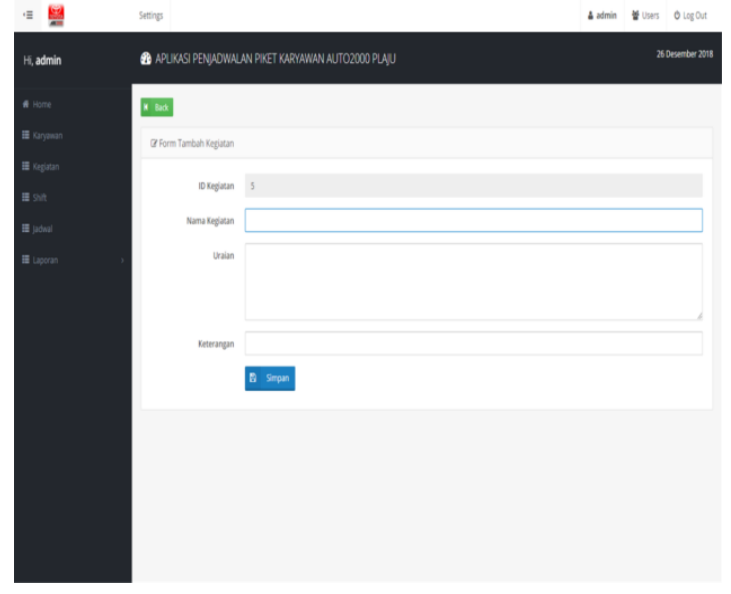

Gambar 7. Kegiatan Piket Karyawan.

4. Halaman Input Data Shift Piket

Tampilan ini untuk menginput data shift karyawan Auto 2000 palembang.

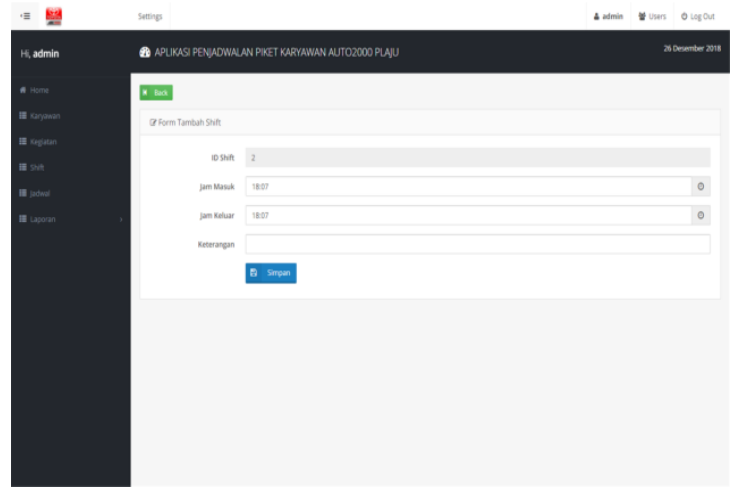

Gambar 8. Entry Data Shift Piket

5. Halaman Input Data Jadwal Piket

Tampilan ini untuk menginput data jadwal piket karyawan Auto2000 Palembang.

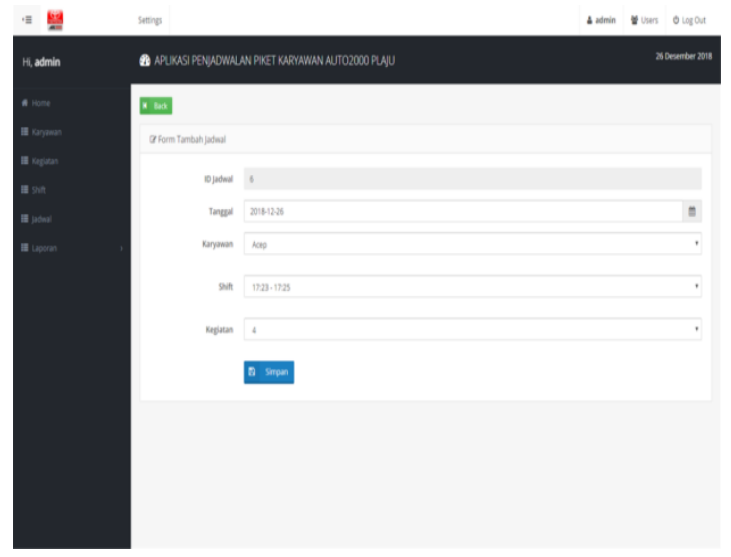

Gambar 9. Entry Data Jadwal Piket
6. Halaman Menu Laporan Karyawan

Tampilan ini untuk melihat data laporan Karyawanyang ada pada Auto 2000 Palembang.

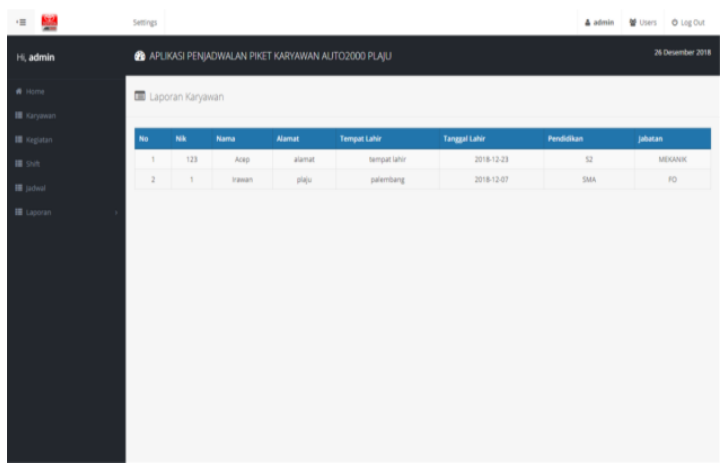

Gambar 10. Menu Laporan Karyawan

7. Halaman Laporan Kegiatan

Tampilan ini untuk melihat data laporan kegiatan yang ada pada Auto 2000 Palembang.

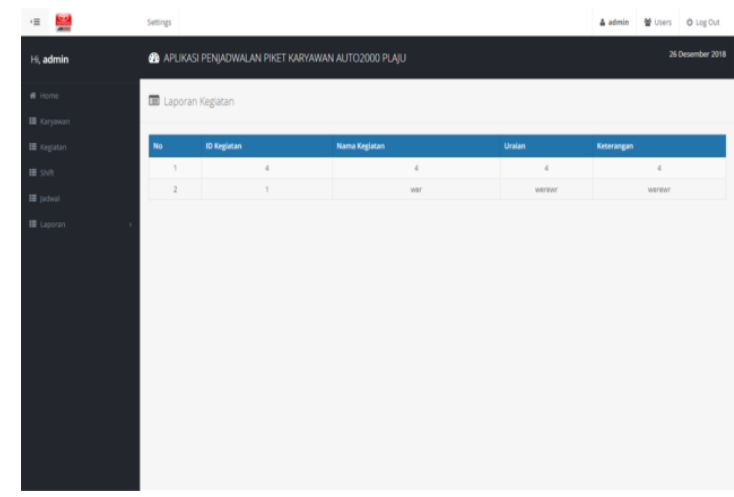

Gambar 11 Menu Laporan Kegiatan piket karyawan

8. Halaman Menu Laporan Shift

Tampilan ini untuk melihat data laporan Shift Karyawan yang ada pada Auto 2000 palembang.

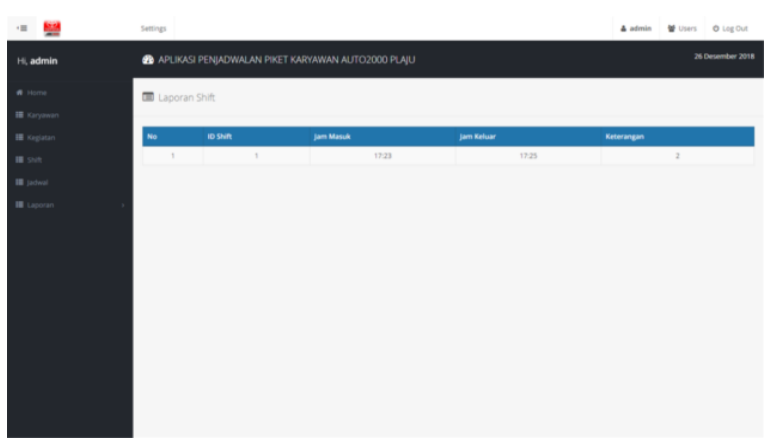

Gambar 12 Menu Laporan Shift 
9. Halaman Menu Laporan Jadwal

Tampilan ini untuk melihat data laporan dari jadwal piket karyawan Auto 2000 Palembang.

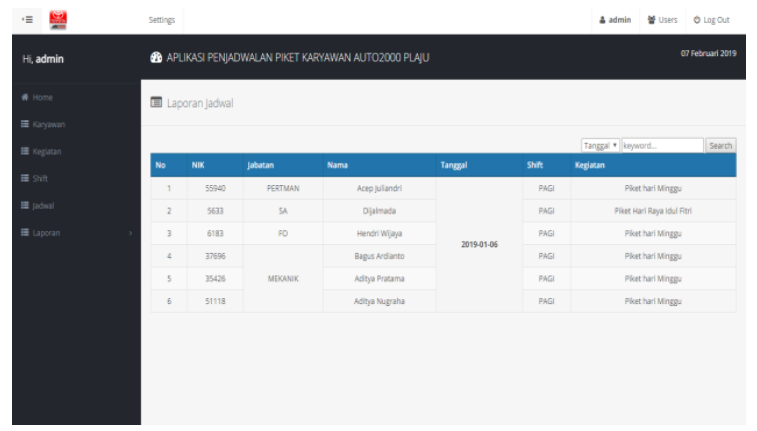

Gambar 13 Tampilan Menu Laporan Jadwal

10. Halaman Menu Laporan Jadwal Piket Perkaryawan

Tampilan ini untuk melihat data laporan dari jadwal piket karyawan Auto 2000 Palembang (perkaryawan).

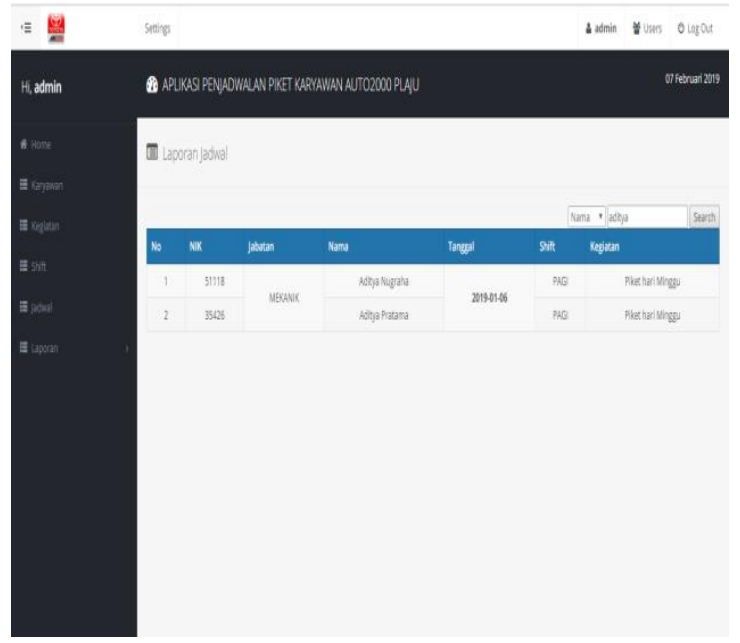

Gambar 14 Menu Laporan Jadwal Piket

Perkaryawan

11. Halaman Menu Laporan Jadwal Piket Pertanggal

Tampilan ini untuk melihat data laporan dari jadwal piket karyawan Auto 2000 Palembang (pertanggal).

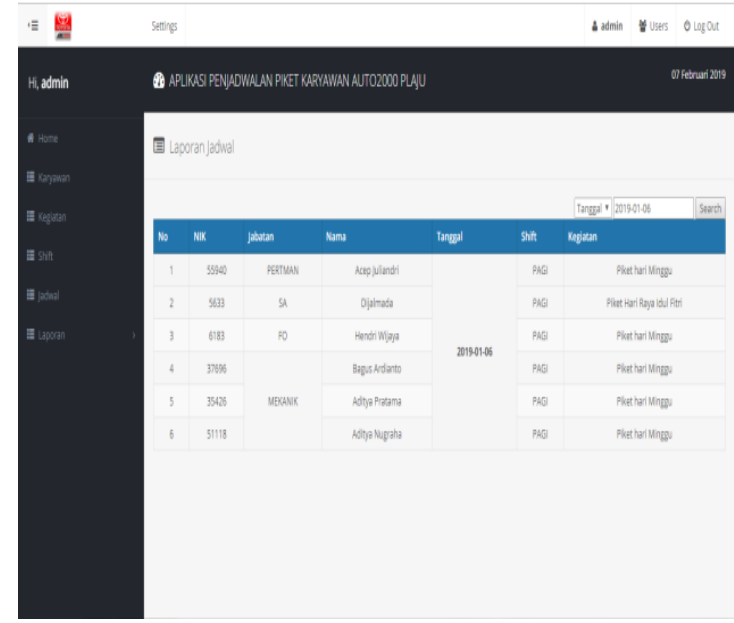

Gambar 15 Menu Laporan Jadwal Piket Pertanggal

\section{SIMPULAN}

Adapun kesimpulan yang dapat diambil dalam penelitian ini adalah; Penelitian ini menghasilakan aplikasi penjadwalan piket karyawan pada Auto2000 plaju Palembang dibuat dengan menggunakan bahasa pemrograman $P H P$ yang berbasis $W e b$. Apilkasi yang dibangun dapat diimplementasikan untuk memudahkan dalam melakukan penjadawalan Piket Karyawan Auto 2000 Palembang pada hari libur yang selama ini dilakukan dengan menggunakan Aplikasi dari Microsoft Excel. Dengan sistem yang baru maka pembuatan jadwal piket karyawan auto 2000 Palembang yang bertugas pada hari libur tidak terjadi keterlambatan dan mengurangi terjadinya kesalahan pencatatan jadwal piket karyawan Auto2000 Palembang. 


\section{DAFTAR RUJUKAN}

Agus Saputra. 2011. Trik Solusi jitu Pemrograman PHP. Jakarta : IKAPI

Andrie Tri Laksono, Meinarini Catur Utami, Yuni Sugiarti, (2016) Sistem Penjadwalan Kuliah Menggunakan Metode Algoritma Genetika (Studi Kasus: Fakultas Kedokteran Dan Kesehatan Universitas Muhammadiyah Jakarta). Studia Informatika: Jurnal Sistem Informasi, pp: 177-188.

Baker, R., dan Trietsch, D., 2009, Principles of Sequencing and Scheduling, John Wiley \& Sons, New York.

Jogiyanto, Hartono.2004. Pengenalan Komputer. Yogyakarta: Andi Offset

Pinedo, M. L. (2012). Scheduling: Theory, Algorithms, and Systems 4th Edition. New Jersey : Springer

Raharjo, Budi. 2011. Belajar otodidak membuat database menggunakan MySQL. Bandung : Informatika.

Pressman. R.S. 2010. Software Engineering a practitioner's approach. McGraw-Hill.

Sugiyono. 2013.. Metode Penelitian Pendidikan Pendekatan Kuantitatif, Kualitatif, dan $R \& D$ Bandung: Alfabeta. 